See discussions, stats, and author profiles for this publication at: https://www.researchgate.net/publication/333681338

\title{
Active monitoring of airborne elements in Isparta Province (Turkey) with the epiphytic lichen Physcia aipolia (Erh. ex Humb.) Fürnr.
}

Article in Journal of Elementology · June 2019

DOI: 10.5601/jelem.2019.24.1.1689

\section{CITATION}

1

2 authors:

Mustafa Yavuz

Istanbul Medeniyet Universitesi

58 PUBLICATIONS 101 CITATIONS

SEE PROFILE
READS

89

Gülşah Çobanoğlu

Marmara University

59 PUBLICATIONS 298 CITATIONS

SEE PROFILE

Some of the authors of this publication are also working on these related projects:

Project Definitions of Life View project

Project History of Lichens View project 
Yavuz M., Çobanoğlu G. 2019.

Active monitoring of airborne elements in Isparta Province (Turkey)

with the epiphytic lichen Physcia aipolia (Erh. ex Humb.) Fürnr.

J. Elem., 24(3): 1115-1128. DOI: 10.5601/jelem.2019.24.1.1689

\title{
ACTIVE MONITORING OF AIRBORNE ELEMENTS IN ISPARTA PROVINCE (TURKEY) WITH THE EPIPHYTIC LICHEN PHYSCIA AIPOLIA (ERH. EX HUMB.) FÜRNR*
}

\author{
Mustafa Yavuz ${ }^{1}$, Gülşah Çobanoğlu² \\ ${ }^{1}$ History of Science Department \\ Istanbul Medeniyet University, Turkey \\ ${ }^{2}$ Department of Biology \\ University of Marmara, Istanbul, Turkey
}

\begin{abstract}
Air pollutants pose a threat to biodiversity throughout the world. This study was conducted to evaluate atmospheric element accumulation in Isparta city, including Gölcük Nature Park, located in the Western Mediterranean Region of Turkey. It is aimed to determine the air quality and potential pollutant sources in the region through lichen biomonitoring. Specimens of the epiphytic foliose lichen Physcia aipolia (Erh. ex Humb.) Fürnr. were sampled from 14 sites in the study area and analyzed by ICP - MS with reference material in order to detect 11 trace elements; $\mathrm{Al}, \mathrm{As}, \mathrm{Cd}, \mathrm{Cr}, \mathrm{Cu}, \mathrm{Fe}, \mathrm{Mn}, \mathrm{Ni}, \mathrm{Pb}, \mathrm{V}$, and $\mathrm{Zn}$. The spatial distribution of these airborne elements in the study area was mapped. The results showed that the elemental sequence in terms of average concentrations measured was as follows: $\mathrm{Ni}>\mathrm{Cr}>\mathrm{V}>\mathrm{Fe}>\mathrm{As}>\mathrm{Al}>\mathrm{Zn}>\mathrm{Cu}>$ $>\mathrm{Cd}>\mathrm{Mn}>\mathrm{Pb}$. The results of cluster analyses of the elemental data indicated that the 3 major contaminants in the urban area were $\mathrm{Cr}, \mathrm{Ni}$, and $\mathrm{V}$, probably due to the extensive use of coal in heating facilities and gasoline in vehicles. $P$. aipolia specimens accumulated maximal concentrations of $\mathrm{As}, \mathrm{Cr}, \mathrm{Fe}, \mathrm{Ni}$, and $\mathrm{V}$ in the northern and the south-eastern localities surrounding the city, while $\mathrm{Cd}, \mathrm{Pb}$ were most abundant in the eastern edge of Gölcük Nature Park. The pollution in Isparta city with heavy metal is worse than expected, mostly due to the extensive use of coal as fossil fuel. In addition, it seems to be associated with the city's topographic and climatic characteristics, e.g. inversion effects.
\end{abstract}

Keywords: lichen, airborne elements, biomonitoring, Isparta.

Mustafa Yavuz, PhD, Asst. Prof., History of Science Department, Istanbul Medeniyet University, Faculty of Arts and Humanities, South Campus TR-34000, Istanbul, Turkey, e-mail: mustafay007@gmail.com

* This research was financially supported by Marmara University, Scientific Research Fund:

FEN-DKR-290506-0126. 


\section{INTRODUCTION}

Lichens are by definition symbiotic organisms, usually composed of a fungal partner, the mycobiont, and one or more photosynthetic partners, the photobiont, which is most often either a green alga or a cyanobacterium. Being sensitive to environmental changes due to their biological characteristics and symbiotic lifestyle (Hawksworth, Rose 1976), lichens are sensitive bioindicators of air pollution, climatic changes, forest structures and dynamics regarding the quality of biodiversity (GIORDANI et al. 2012). They are slow-growing organisms, so they remain in place for many years. Since lichens have neither roots nor a protective cuticle layer and therefore absorb air pollutants together with moisture mainly through the thallus surface, they are vulnerable to effects of any atmospheric contaminants (GARTY 2001, WolterbeeK et al. 2003). Therefore, concentrations of trace elements in lichen thalli indicate the environmental levels for the mentioned elements (BARI et al. 2001). The use of lichens for biomonitoring facilitates many aspects, for example sampling is easy and costs are low; this given an advantage to lichen in spatial and temporal assessment of the level of pollutants in the environment (LopPI et al. 2003, ScERBo et al. 2003).

Despite the growing number of lichen biomonitoring studies carried out in Turkey for many years: Aslan et al. (2004) - Erzurum, Yenisoy-Karakas,, Tuncel (2004) - the Aegean region, Mendil et al. (2005) - Trabzon, ÇAYIR et al. (2007) - Çanakkale and Balıkesir, YILdız et al. (2008) - Ankara, İçEL, ÇobanoĞLu (2009) - İstanbul, Şenkardeşler, Aysel (2010) - İzmir, Ölgen, GÜr (2012) - Muğla, DoĞRul-Demiray et al. (2012) - Kocaeli, Bozkurt (2017) - Düzce, Kurnaz, ÇoBanoĞLu (2017) - İstanbul, YILDIZ et al. (2018) - Çorum, the Isparta Region has not been submitted to such research before. Isparta is a city located in the Mediterranean Region of Turkey. At the end of the 1990s, Isparta experienced a high and uncontrolled increase in population, followed by chaotic urbanization. Although serious measures were taken to reduce and control this rise in population and urbanization, certain environmental problems occurred in Isparta Province. Industrial zones are concentrated to the north-northeast of the city. As mentioned in the detailed report by Demir (2010), there are various workshops and some factories, mainly in the forestry and carpentry (51 facilities), food and beverage (46), metal equipment (34), cement and marble (28), textile and leather (25), petro-chemistry and paint (19), cosmetics (4), and fertilizers (1) branches. Wood, coal and fuel oil are widely used in the province for residential home heating, and a total of 102,920,456 kg of coal was consumed between April 2008 and April 2009 in the city centre.

In addition to the industrial facilities, a major highway between Afyonkarahisar and Antalya passes through the centre of Isparta, being another potential source of airborne pollutants. Air quality assessment carried out by the local authorities in Isparta is based on the monitoring of $\mathrm{PM}_{10}$ and $\mathrm{SO}_{2}$. 
The main objectives of this study, where the air quality of Isparta city is assessed by lichen biomonitoring, are to examine the degree of metal deposition in Isparta via quantitative analyses, and to determine the relationship between potential pollutant sources and levels of airborne metals. Considering that air pollutants can be transported over very long distances by environmental factors such as wind (ÇOBANOĞLU 2015), a nature park lying within the provincial borders and even the surrounding area may be at risk. For this reason, Gölcük Nature Park (GNP), situated close to the city, was also included in this study. The principal goal is to establish the baseline for future biomonitoring studies in Isparta.

\section{MATERIALS AND METHODS}

\section{Study area}

The study area is the surroundings of Isparta city center, which is located in the North-Western Mediterranean Region, Turkey (Figure 1). In this Turkish region, an urban area is usually surrounded by industrial zones located along highways. The southern part of the city is mountainous, while the western part is sporadically hilly, and - due to these geographical peculiarities - industrial zones are located in north-eastern and northern parts of the urban area. The northern and eastern suburbs are surrounded by agricultural fields as well.

Isparta has the Semi-Arid Mediterranean climate with a mean annual rainfall of $506 \mathrm{~mm}$ and a mean annual temperature of $12^{\circ} \mathrm{C}$. The prevalent winds in the region are from the south-west $\left(9 \mathrm{~m} \mathrm{~s}^{-1}\right)$, from south $\left(8.1 \mathrm{~m} \mathrm{~s}^{-1}\right)$, from south-east $\left(6 \mathrm{~m} \mathrm{~s}^{-1}\right)$, and from west (1.6 $\left.\mathrm{m} \mathrm{s}^{-1}\right)$ (IмIM, 2010)

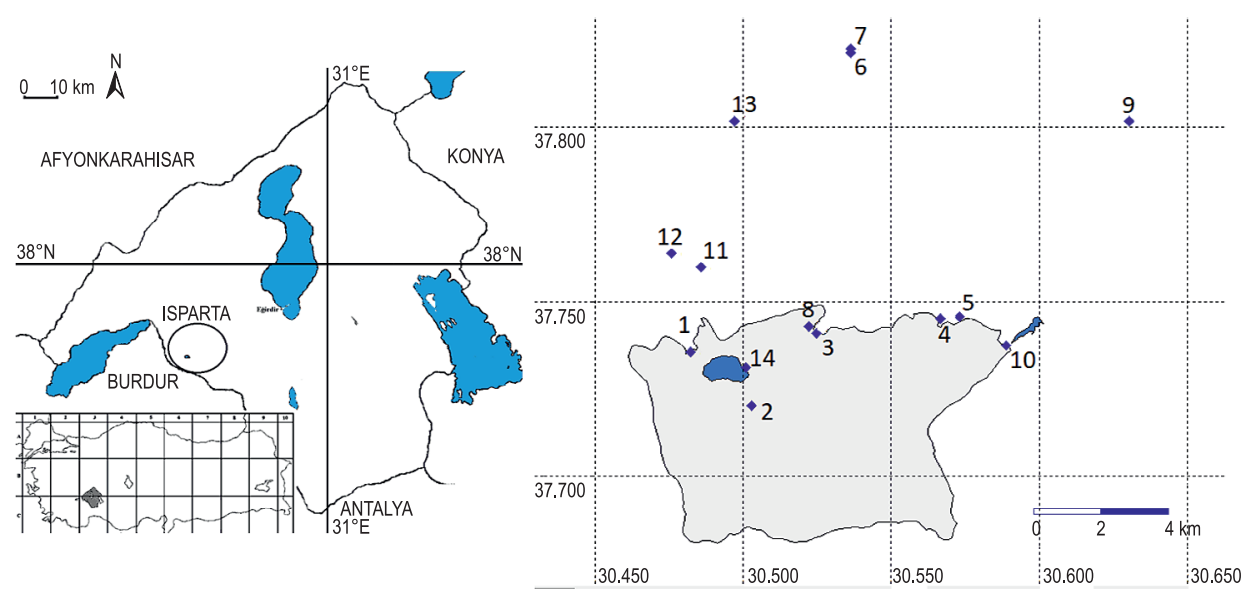

Fig. 1. The study area (indicated with a circle on the left map) and the sampling sites 


\section{Lichen sampling}

The epiphytic-foliose cosmopolite lichen Physcia aipolia was selected as a biomonitoring organism in the study, owing to its widespread presence both in urban areas and in wildlife parks, and to its high tolerance to atmospheric pollution. Lichen sampling was carried out from April 2009 to July 2010. Samples were collected from 14 sampling stations distributed around the major industrialized and suburban areas of Isparta (Figure 1).

A composite lichen sample was made from randomly collected specimens at every sampling station, found by exploring an area of $50 \times 50 \mathrm{~m}$. In each locality, 15 samples of lichen rosettes $\geq 2 \mathrm{~cm}$ in diameter were selected as biomonitoring samples, and were taken from the bark of trees (Amygdalus sp., Pinus nigra, Populus alba, Populus nigra, Prunus domesticus, Robinia pseudacacia and Sorbus sp.) at a height of at least $120 \mathrm{~cm}$ above the ground in order to avoid terrestrial contamination. In the laboratory, lichen samples were air-dried and stored in polyethylene bags until chemical analysis. GPS and altitude information of the localities was recorded by a Garmin e-trex summit device, as given in Table 1 .

Table 1

Geographical data of sampling locations in the study area

\begin{tabular}{|c|l|c|c|c|}
\hline No & \multicolumn{1}{|c|}{ Locality } & \multicolumn{1}{|c|}{ GPS Coordinates } & $\begin{array}{c}\text { Altitude } \\
(\mathrm{m})\end{array}$ & Date \\
\hline $\mathbf{1}$ & GNP, North-Western Slopes of Crater & $37^{\circ} 44^{\prime} 07.70^{\prime \prime} \mathrm{N}-30^{\circ} 28^{\prime} 57.20^{\prime \prime} \mathrm{E}$ & 1454 & 23.05 .2009 \\
\hline $\mathbf{2}$ & GNP, South-Eastern Slopes of Crater & $37^{\circ} 43^{\prime} 13.30^{\prime \prime} \mathrm{N}-30^{\circ} 30^{\prime} 13.70^{\prime \prime} \mathrm{E}$ & 1464 & 07.06 .2009 \\
\hline $\mathbf{3}$ & Between Bezirgân and Hisartepe Hill & $37^{\circ} 44^{\prime} 26.65^{\prime \prime} \mathrm{N}-30^{\circ} 31^{\prime} 30.33^{\prime \prime} \mathrm{E}$ & 1294 & 14.06 .2009 \\
\hline $\mathbf{4}$ & Sidre Hill & $37^{\circ} 44^{\prime} 41.50^{\prime \prime} \mathrm{N}-30^{\circ} 34^{\prime} 00.00^{\prime \prime} \mathrm{E}$ & 1191 & 11.04 .2009 \\
\hline $\mathbf{5}$ & Halife Sultan Cemetery & $37^{\circ} 44^{\prime} 44.13^{\prime \prime} \mathrm{N}-30^{\circ} 34^{\prime} 23.82^{\prime \prime} \mathrm{E}$ & 1126 & 11.04 .2009 \\
\hline $\mathbf{6}$ & Çünür Hill South Slope & $37^{\circ} 49^{\prime} 15.80^{\prime \prime} \mathrm{N}-30^{\circ} 32^{\prime} 11.92^{\prime \prime} \mathrm{E}$ & 1070 & 11.04 .2009 \\
\hline $\mathbf{7}$ & Çünür Hill North Slope & $37^{\circ} 49^{\prime} 20,00^{\prime \prime} \mathrm{N}-30^{\circ} 32^{\prime} 11,30^{\prime \prime} \mathrm{E}$ & 1070 & 11.04 .2009 \\
\hline $\mathbf{8}$ & Bezirgân Picnic Area & $37^{\circ} 44^{\prime} 33.50^{\prime \prime} \mathrm{N}-30^{\circ} 31^{\prime} 20.50^{\prime \prime} \mathrm{E}$ & 1246 & 16.06 .2009 \\
\hline $\mathbf{9}$ & Küçük Hacılar Village & $37^{\circ} 48^{\prime} 05.60^{\prime \prime} \mathrm{N}-30^{\circ} 37^{\prime} 49.40^{\prime \prime} \mathrm{E}$ & 972 & 18.04 .2010 \\
\hline $\mathbf{1 0}$ & Darı River Basin & $37^{\circ} 44^{\prime} 14.40^{\prime \prime} \mathrm{N}-30^{\circ} 35^{\prime} 20.60^{\prime \prime} \mathrm{E}$ & 1105 & 18.04 .2010 \\
\hline $\mathbf{1 1}$ & Gülbirlik Rose-oil Factory & $37^{\circ} 45^{\prime} 34.80^{\prime \prime} \mathrm{N}-30^{\circ} 29^{\prime} 09.90^{\prime \prime} \mathrm{E}$ & 1215 & 24.04 .2010 \\
\hline $\mathbf{1 2}$ & Gelincik Village & $37^{\circ} 45^{\prime} 50.00^{\prime \prime} \mathrm{N}-30^{\circ} 28^{\prime} 33.70^{\prime \prime} \mathrm{E}$ & 1218 & 24.04 .2010 \\
\hline $\mathbf{1 3}$ & Kayı Village West & $37^{\circ} 48^{\prime} 05.30^{\prime \prime} \mathrm{N}-30^{\circ} 29^{\prime} 49.70^{\prime \prime} \mathrm{E}$ & 1106 & 24.04 .2010 \\
\hline $\mathbf{1 4}$ & GNP, North-Eastern Part & $37^{\circ} 43^{\prime} 53.30^{\prime \prime} \mathrm{N}-30^{\circ} 30^{\prime} 02.50^{\prime \prime} \mathrm{E}$ & 1390 & 22.07 .2010 \\
\hline
\end{tabular}




\section{Analysis of element contents}

Lichen samples were carefully cleaned with plastic tweezers to remove pieces of bark and extraneous materials. Then, clean samples were places in in deionized water and stirred for thirty seconds to remove the dust over the surface of thalline samples. Clean samples were dried for $24 \mathrm{~h}$ at room temperature and then for $18 \mathrm{~h}$ at $105^{\circ} \mathrm{C}$ of incubation. The dried thalli of the lichen samples were subsequently ground and homogenized with an agate mortar and pestle. During digestion of the lichen samples, $200 \mathrm{mg}$ of dry powdered sample were digested in a mixture of $10 \mathrm{~mL} \mathrm{2:8:2} \mathrm{HCl}: \mathrm{HNO}_{3}: \mathrm{H}_{2} \mathrm{O}_{2}$ at $180 \mathrm{psi}$ pressure, $15 \mathrm{~min}$ between $0-95^{\circ} \mathrm{C}, 1 \mathrm{~min}$ at $95^{\circ} \mathrm{C}$ and finally $15 \mathrm{~min}$ between $95-200^{\circ} \mathrm{C}$ (CEM - Mars Xpress Microwave) The digestion solution was finally diluted to $20 \mathrm{~mL}$ with ultra-pure water and analyzed for $\mathrm{Al}$, As, $\mathrm{Cd}, \mathrm{Cu}, \mathrm{Fe}, \mathrm{Mn}, \mathrm{Ni}, \mathrm{Pb}, \mathrm{V}$ and $\mathrm{Zn}$ with ICP-MS (ACME Analytical Labs., Canada). Analytes were selected mainly based on the potential pollutant sources in Isparta. Efficiency of the digestion procedure and the quality of analytical results were evaluated by analyzing certified reference material, IAEA-336 Lichen (International Atomic Energy Agency, Vienna), with the same procedures as adopted for the samples. Precision of analyses was found to be less than $5 \%$ for all elements analyzed (Table 2).

For each element analyzed, a contour map was drawn using Surfer®15 software package. The Kriging algorithm with a gridding method was used to create the contour maps representing the aerial distribution of metal concentrations in Isparta.

\section{Statistical analyses}

Correlation and cluster analyses were performed on the analytical data to evaluate the relationship between the pollutants and possible pollutant sources. Correlations between elements were tested by the Pearson's correlation test $(p<0.01,0.05)$. Two-tailed significance values $(n=15, a=0.01$, $\left.r_{\text {crit }}=0.6411 ; n=15, \alpha=0.05, r_{\text {crit }}=0.5140\right)$ were used for the correlation test. Cluster analysis of all elemental data from the urban and the industrial districts of Isparta were conducted separately using a Statistica ${ }^{\circledR} 12$ package. The complete linkage clustering method and squared Euclidean distance metric were used in the cluster analysis.

\section{RESULTS}

\section{Element analyses}

The analysis of certified reference material to calibrate the measurements showed that the concentrations of almost all elements analyzed were found within the limits of certified values (Table 2). The IAEA reference sheet does not provide a recommended value for the $\mathrm{Ni}$ element concentration. 
Concentrations $\left(\mu \mathrm{g} \mathrm{g}^{-1}\right)$ of elements in lichens collected from 14 sites in Isparta

\begin{tabular}{|c|c|c|c|c|c|c|c|c|c|c|c|}
\hline Locality & $\mathrm{Al}$ & As & Cd & $\mathrm{Cr}$ & $\mathrm{Cu}$ & $\mathrm{Fe}$ & Mn & $\mathrm{Ni}$ & $\mathbf{P b}$ & V & $\mathrm{Zn}$ \\
\hline 1 & 4121.61 & 4.56 & 0.20 & 14.99 & 10.93 & 3882.26 & 169.80 & 20.82 & 7.41 & 19.88 & 308.32 \\
\hline 2 & 3806.92 & 5.87 & 0.11 & 14.73 & 13.55 & 3437.62 & 118.60 & 27.01 & 6.73 & 19.15 & 112.92 \\
\hline 3 & 3755.27 & 4.44 & 0.08 & 17.25 & 16.80 & 3876.56 & 120.20 & 113.90 & 7.69 & 17.60 & 184.62 \\
\hline 4 & 3813.52 & 6.24 & 0.11 & 14.87 & 16.43 & 3554.65 & 99.92 & 135.08 & 6.26 & 20.93 & 98.72 \\
\hline 5 & 6020.63 & 7.69 & 0.08 & 33.72 & 17.12 & 5960.87 & 102.00 & 81.14 & 8.44 & 31.76 & 105.42 \\
\hline 6 & 4696.36 & 7.03 & 0.10 & 18.55 & 16.47 & 4108.15 & 161.70 & 243.40 & 5.94 & 23.48 & 75.43 \\
\hline 7 & 3351.16 & 6.52 & 0.08 & 16.43 & 13.82 & 3497.80 & 76.68 & 12.56 & 6.11 & 16.20 & 227.32 \\
\hline 8 & 5110.48 & 6.08 & 0.13 & 16.76 & 17.45 & 4849.12 & 204.80 & 137.90 & 11.27 & 32.15 & 188.12 \\
\hline 9 & 5242.45 & 5.11 & 0.15 & 16.05 & 12.22 & 4579.32 & 234.30 & 12.43 & 6.15 & 24.75 & 229.62 \\
\hline 10 & 6084.34 & 6.03 & 0.11 & 47.69 & 16.84 & 8122.75 & 312.90 & 77.32 & 9.15 & 34.42 & 198.62 \\
\hline 11 & 3051.73 & 5.33 & 0.07 & 9.34 & 21.45 & 3115.62 & 194.60 & 12.23 & 10.09 & 17.10 & 135.52 \\
\hline 12 & 7131.01 & 6.87 & 0.40 & 21.64 & 22.70 & 7153.04 & 367.40 & 104.60 & 16.08 & 33.65 & 201.72 \\
\hline 13 & 5812.81 & 6.29 & 0.18 & 26.02 & 20.22 & 5684.41 & 272.23 & 48.41 & 17.26 & 24.97 & 136.71 \\
\hline 14 & 1884.40 & 1.29 & 4.92 & 2.96 & 16.63 & 1445.50 & 99.61 & 12.66 & 20.71 & 3.86 & 77.07 \\
\hline Mean & $4,563.05$ & 5.67 & 0.48 & 19.36 & 16.62 & $4,519.12$ & 181.05 & 74.25 & 9.95 & 22.85 & 162.87 \\
\hline SD & 1421.89 & 1.56 & 1.28 & 10.81 & 3.46 & 1732.50 & 88.78 & 67.90 & 4.74 & 8.40 & 67.94 \\
\hline $\begin{array}{l}\text { IAEA } \\
\text { (Certified) }\end{array}$ & 680.00 & 0.63 & 0.12 & 1.06 & 3.60 & 430.00 & 63.00 & $\cdots$ & 4.90 & 1.47 & 30.40 \\
\hline $\begin{array}{l}\text { IAEA } \\
\text { (Measured) }\end{array}$ & 661.20 & 0.62 & 0.11 & 1.11 & 3.55 & 413.44 & 60.60 & 2.45 & 4.75 & 1.41 & 28.91 \\
\hline $\begin{array}{l}\text { Confidence } \\
(\%)\end{array}$ & 97.24 & 97.95 & 95.73 & 95.22 & 98.53 & 96.15 & 96.19 & $\cdots$ & 96.89 & 95.81 & 95.10 \\
\hline
\end{tabular}

The concentrations of the elements detected in lichen samples collected from the study area are given in Table 2 .

\section{Spatial distribution of elements}

According to data from the multi-element analysis, the order of the average concentrations of elements in the study area was as follows: $\mathrm{Ni}>\mathrm{Cr}>\mathrm{V}>$ $>\mathrm{Fe}>\mathrm{As}>\mathrm{Al}>\mathrm{Zn}>\mathrm{Cu}>\mathrm{Cd}>\mathrm{Mn}>\mathrm{Pb}$ (Figure 2). The 3 major contaminants in the research area are $\mathrm{Ni}, \mathrm{Cr}$, and $\mathrm{V}$, probably due the extensive use of coal in heating facilities and gasoline in vehicles. P. aipolia specimens tend to have the maximal $\mathrm{As}, \mathrm{Cr}, \mathrm{Fe}$, and $\mathrm{V}$ concentrations in the southern and the south-eastern localities, while the $\mathrm{Al}, \mathrm{Cu}$ and $\mathrm{Mn}$ concentrations are the highest in lichens from the western sites surrounding the city. Interestingly, $\mathrm{Cd}$ and $\mathrm{Pb}$ concentrations reached the maximum amounts in lichens from the eastern edge of GNP. The pollution with heavy metals in Isparta city is worse than expected due to the extensive use of coal as fossil fuel. In addi- 


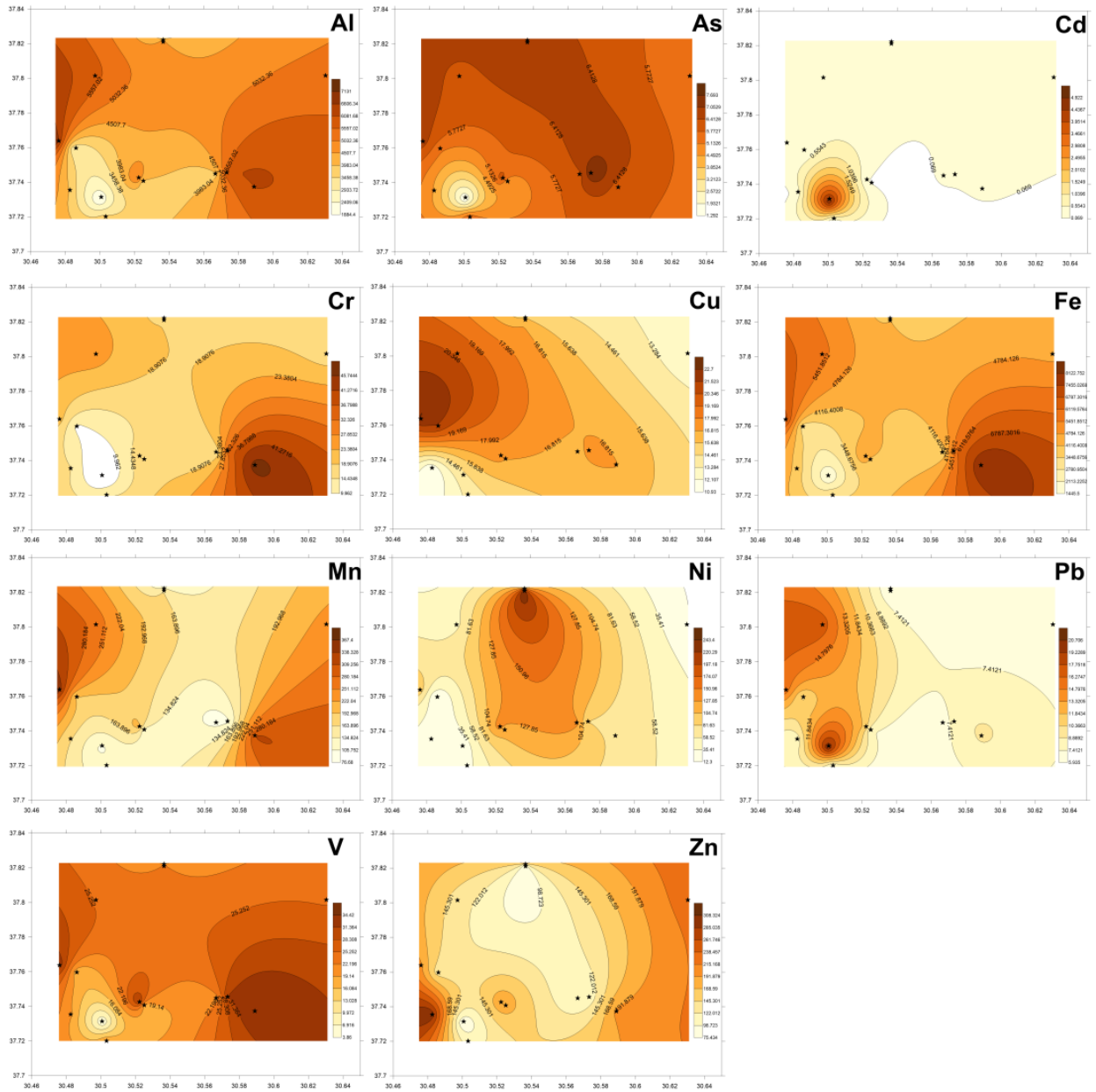

Fig. 2. Spatial distribution maps of 11 airborne elements in the study area

tion, it seems to be associated with the city's topographic and climatic characteristics.

In Isparta, $\mathrm{Al}$ is used in cars, trucks, doors and windows as a construction material; As and $\mathrm{Cd}$ are used in the textile dyeing industry, in some agricultural pesticides and are emitted by coal-fired heating; $\mathrm{Cr}$ is consumed in the textile and refrigerant industries; $\mathrm{Cu}$ and Fe are used in the dyeing industry, and are emitted by coal-fired furnaces; Fe is also used in the construction and metal works; Mn is used in ceramics, tile and brick production as well as in the dyeing industry; $\mathrm{Ni}, \mathrm{Pb}, \mathrm{V}$ and $\mathrm{Zn}$ are emitted by coal-fired heating and in exhaust fumes from cars; V and $\mathrm{Zn}$ are also used in the dyeing, textile, plastic and cosmetics industries.

Sites nos 1, 2, 3, 8, 11 and 14 on the border of GNP are relatively far from 
urban pollution. The other eight localities are either in or near the urban area, and are closer to possible sources of pollution. Spatial distributions of the element concentrations in the survey area are shown in Figure 2.

\section{Statistical analyses}

The cluster analysis revealed two main clusters of elements, as given in Figure 3. Cluster $a$ consists of $\mathrm{Al}$ and $\mathrm{Fe}$, while cluster $b$ is divided into

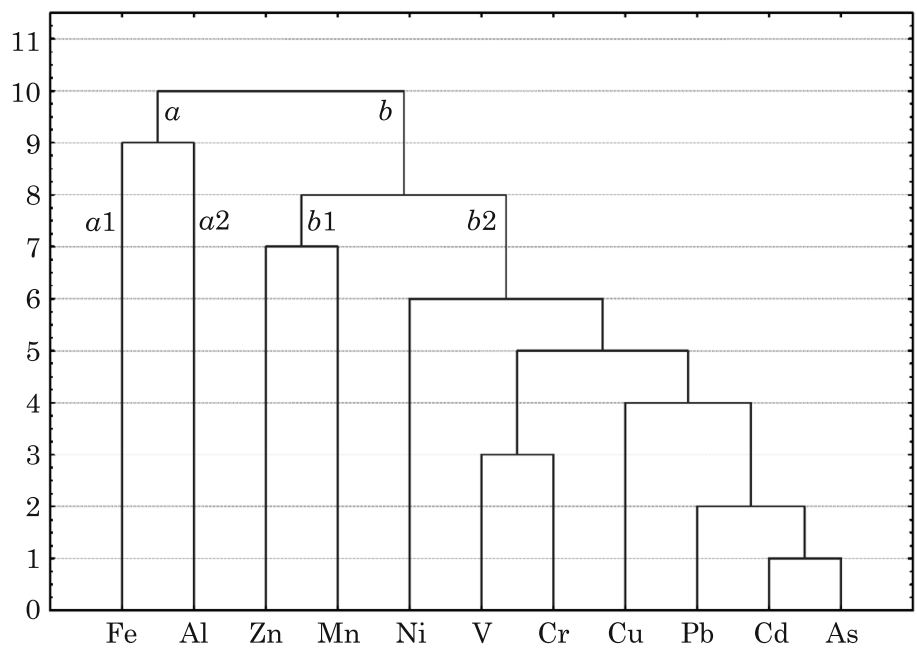

Fig. 3. Dendrogram of elements in lichen samples from 14 sites in Isparta

two sub-groups, such as $b 1$ of $\mathrm{Mn}-\mathrm{Zn}$ and $b 2$ including $\mathrm{Ni}$ and the rest of the analytes. The elements given in cluster $a(\mathrm{Al}-\mathrm{Fe})$, cluster $b 2(\mathrm{Ni})$ and cluster of $\mathrm{Cr}-\mathrm{V}$ show strong mutual correlations (Al-Fe: $r=0.93, \mathrm{Al}-\mathrm{V}$ : $\left.r=0.93, \mathrm{Fe}-\mathrm{V}: r=0.91, \mathrm{Fe}-\mathrm{Cr}: r=0.89, p<0.01, r_{\text {crit }}=0.64\right)$. As reported by RAUCH, PACYNA (2009), the emission source of these elements is fossil fuel combustion (coal).

\section{DISCUSSION}

Pollution of the environment is one of many problems in the contemporary world. It has been realized that air pollution leads to important problems that threaten human health and ecosystems. For this reason, most city administrations conduct air quality monitoring studies. Biological monitoring (with lichens or mosses) continues to provide valuable data even if it has not yet entered the agenda of local governments.

As stated above, the results of air quality monitoring done between August 2006 and June 2010 by the local authorities, responding to the 
Ministry of Environment, have been reported in terms of $\mathrm{SO}_{2}$ and $\mathrm{PM}_{10}$. The mean concentration of $\mathrm{SO}_{2}$ in winter seasons is $122 \mu \mathrm{g} \mathrm{m}^{-3}$, while that of $\mathrm{PM}_{10}$ is $91 \mu \mathrm{g} \mathrm{m}^{-3}$ in the city center. Although the levels of $\mathrm{SO}_{2}$ have been decreasing since the local authorities began to control the quality of coal combusted in the city, there is still a considerable concentration of $\mathrm{SO}_{2}$ and $\mathrm{PM}_{10}$ in the atmosphere, which corresponds to the result of analytes given in this study. The evaluation of multiple element ratios with lichen monitoring can be performed in parallel with the airborne PM, since it is a complex mixture of a number of components, including acids, organic chemicals, metals, soil or dust particles and allergens (such as fragments of pollen or mold spores) in the air (Dominici et al. 2015, EPA 2017). The long-term exposure to particulate matter in the air has been well documented for its harmful effect on human health, and strong association has been demonstrated between PM levels and mortality rates (Di et al. 2017). PATERAKI et al. (2012) examined the role of meteorological conditions on different-sized PM differentiation, and showed that the formation of fine particles was strongly related to temperature and humidity fluctuations and wind direction. Recent studies indicate the association between fine particle matter $\left(\mathrm{PM}_{2.5}\right)$ and lung cancer (LC) mortality (HE et al. 2018). Based on the reports by the local authorities, in terms of $\mathrm{SO}_{2}$ and $\mathrm{PM}_{10}$, these monitoring studies may be misleading and inadequate to assess air quality, particularly in industrial centers and in cities that are heated by coal combustion. Unfortunately, there are no data available for fine particulate matter $\left(\mathrm{PM}_{2.5}\right)$ in Isparta city.

According to the results of the present study, element concentrations determined in descending order, Ni, Cr, V, Fe, As, Al, Zn, Cu, Cd, Mn and $\mathrm{Pb}$, represent the concentrations of the elements that are generally high in industrial regions. For instance, in a transplantation study with the lichen Parmotrema tinctorum in the Map Ta Phut petrochemical industrial complex in Thailand (BoonPEng et al. 2017), similar findings were reported in terms of concentrations of $\mathrm{As}, \mathrm{Cr}, \mathrm{Ni}, \mathrm{V}$ and $\mathrm{Zn}$ elements at most of the industrial sites. On the other hand, $\mathrm{Cd}$ and $\mathrm{Cu}$ elements were found to be lower in our study.

\section{Comparison of elemental data in the localities}

The heavy metal pollution in Isparta city is higher than expected due to extensive use of coal as fossil fuel, and it seems to be associated with the city's topographic and climatic characteristics such as inversion effects.

The geographical position, location, and topographic features of the city and the localities are crucial during the discussions on the results of the survey. Considering the city center of Isparta, the localities in the south-southwestern parts are on higher altitudes than those in the north and east, as seen in Figure 2 and Table 1. The prevalent winds in the region from southwest $\left(9 \mathrm{~m} \mathrm{~s}^{-1}\right)$, and from south $\left(8.1 \mathrm{~m} \mathrm{~s}^{-1}\right)$ directions sweep airborne par- 
ticles towards north-western, northern and north-eastern parts of the city. This causes the north-eastern part to be contaminated more than the other parts of the city due to the altitude.

According to the data given in Table 2, in site 10 (Darı River Basin, $1105 \mathrm{~m}) \mathrm{Cr}\left(47.69 \mu \mathrm{g} \mathrm{g}^{-1}\right)$, Fe $\left(8,122.75 \mu \mathrm{g} \mathrm{g}^{-1}\right)$, and V $\left(34.42 \mu \mathrm{g} \mathrm{g}^{-1}\right)$; in site 12 (Gelincik Village, $1218 \mathrm{~m}) \mathrm{Al}\left(7,131.01 \mu \mathrm{g} \mathrm{g}^{-1}\right), \mathrm{Cu}\left(22.70 \mu \mathrm{g} \mathrm{g}^{-1}\right)$, and $\mathrm{Mn}$ $\left(367.40 \mu \mathrm{g} \mathrm{g}^{-1}\right)$; and in site 14 (GNP, North-Eastern Part, $\left.1390 \mathrm{~m}\right)$ $\mathrm{Cd}\left(4.92 \mu \mathrm{g} \mathrm{g}^{-1}\right)$, and $\mathrm{Pb}\left(20.71 \mu \mathrm{g} \mathrm{g}^{-1}\right)$ have maximum concentrations. It has been reported that lead $(\mathrm{Pb})$ is usually in the highest concentrations at middle elevations (200-400 m) - GARTY (2001). However, it is quite surprising that it is locally too high at site 14, whose elevation equals $1390 \mathrm{~m}$, and which lies within the park's boundaries. The high concentration of these elements (Al, Cd, Cr, Cu, Fe, Mn, $\mathrm{Pb}$ and $\mathrm{V}$ ) in the mentioned locations indicate that the Physcia aipolia (Erh. ex Humb.) Fürnr. specimens collected from these locations have been contaminated by coal-fired heating and exhaust gas from cars.

The most effective factors determining the extent of pollution include height, wind direction, humidity, temperature, distance to the source of pollution, altitude and the characteristics of a given element (ÇOBANOĞLU 2015, PARzYCH et al. 2016). Due to the topographic peculiarities of the locations, the airborne elements may have been blown by the prevailing wind in the study area. In site 10, the airborne elements may originate from villages and exhaust gas from cars driven on a dirt road, and in site 12 , they may come from coal-heaters used in the nearby greenhouses and villages. Since natural gas is not widely used in the centre, coal-fired heating is the dominant factor of emissions. Site 14 lies at an altitude of $1390 \mathrm{~m}$, which is the third highest locality in the study area. Origin of the emissions may be charcoal used for barbecue, and cars driven on a dirt road. The elemental concentration detected in this locality is not affected directly by the urban area due the difference in the altitude and higher hills separating the urban area and the natural park. Site 14 has the minimum concentrations of $\mathrm{Al}$ $\left(1,884.40 \mu \mathrm{g} \mathrm{g} \mathrm{g}^{-1}\right)$, As $\left(1.29 \mu \mathrm{g} \mathrm{g}^{-1}\right)$, Cr $\left(0.07 \mu \mathrm{g} \mathrm{g}^{-1}\right), \mathrm{Cu}\left(10.93 \mu \mathrm{g} \mathrm{g}^{-1}\right)$, Fe $\left(1,445.50 \mu \mathrm{g} \mathrm{g}^{-1}\right)$, and V $\left(3.86 \mu \mathrm{g} \mathrm{g}^{-1}\right)$.

Site $11(1215 \mathrm{~m})$ shows the minimum concentrations of $\mathrm{Cd}\left(0.07 \mu \mathrm{g} \mathrm{g}^{-1}\right)$ and $\mathrm{Ni}\left(12.23 \mu \mathrm{g} \mathrm{g}^{-1}\right)$. Since this locality is closer to GNP than to the urban area, these results indicate a minimum effect of airborne element emission on the lichen specimens collected.

Sites $3(1294 \mathrm{~m})$ and $8(1246 \mathrm{~m})$ are two localities facing to each other on both sides of a small, narrow valley between GNP and the urban area. Given in Table 2, the element content of Physica aipolia in site 3 is lower than in site 8 except for $\mathrm{Cr}$. This decline in concentrations may be due to the higher altitude of site 3 .

Sites 6 and locality 7 are two localities at the same altitude of $1070 \mathrm{~m}$, ideal for comparison, on the north and south slopes of Çünür Hill, which 
stands next to a motorway starting in the city center and connecting it with the Süleyman Demirel University's campus and leading to the neighboring provinces, Burdur, Denizli and Afyonkarahisar. Çünür Hill is in the north of the industrial area as well. The only difference between these twin localities is the facade facing to South (6) and North (7). The distance of these two localities from emission sources is almost same since they lie only $130 \mathrm{~m}$ from each other. Except $\mathrm{Pb}$ and $\mathrm{Zn}$ elements, site 6 has higher concentrations in all elements and the concentration of $\mathrm{Ni}$ is the maximum $\left(243.40 \mu \mathrm{g} \mathrm{g}^{-1}\right)$ while that of $\mathrm{Zn}$ is the minimum one $\left(75.43 \mu \mathrm{g} \mathrm{g}^{-1}\right)$. In the opposite direction of the same hill, at site 7 , the concentration of $\mathrm{Mn}\left(76,68 \mu \mathrm{g} \mathrm{g}^{-1}\right)$ is at its lowest. The results indicate that the southern slope of Çünür Hill has been affected more than the northern one, since it faces the urban area.

\section{Comparison with other lichen biomonitoring studies in Turkey}

Comparison of average values of our determinations, together with those from previous biomonitoring studies with Physcia species in two other cities in Turkey, i.e. in İstanbul by IçeL, ÇOBANoĞLU (2009), and in Trabzon by Mendil et al. (2005), relative to the reference material IAEA-336 ratios, are given in Table 3 .

Table 3

Comparison of Physcia sp. average concentrations to IAEA-336 ratios

\begin{tabular}{|c|c|c|c|c|c|c|c|c|c|}
\hline & \multirow{2}{*}{\multicolumn{2}{|c|}{$\begin{array}{c}\text { İstanbul } \\
\left(\begin{array}{c}\text { İçEL, ÇOBANOĞLU } \\
\text { 2009) }\end{array}\right. \\
\text { P. adscendens }\end{array}$}} & \multirow{2}{*}{\multicolumn{2}{|c|}{$\begin{array}{c}\text { Trabzon } \\
\text { (MendiL et al., } \\
\text { 2005) }\end{array}$}} & \multirow{2}{*}{\multicolumn{2}{|c|}{$\begin{array}{c}\text { Isparta } \\
\text { (Yavuz, ÇOBANOĞLU, } \\
\text { present study) } \\
\text { P. aipolia }\end{array}$}} & \multirow{3}{*}{ 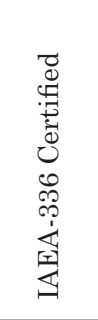 } & \multirow{3}{*}{ 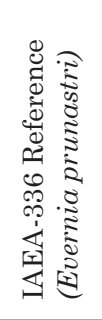 } & \multirow{3}{*}{ 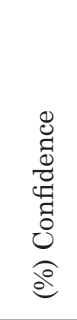 } \\
\hline & & & & & & & & & \\
\hline & 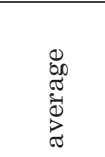 & 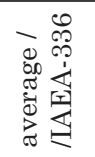 & 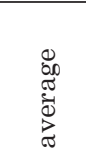 & 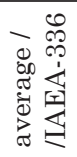 & 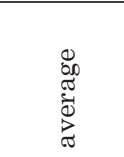 & 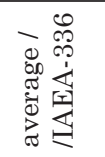 & & & \\
\hline Al &.- & -- & $\cdots$ & $-\cdots$ & $4,563.05$ & 6.71 & 680.00 & 661.20 & 97.24 \\
\hline As & $\ldots$ & -- & -- & -.- & 5.67 & 9.00 & 0.63 & 0.62 & 97.95 \\
\hline Cd & 0.24 & 2.03 & 0.61 & 5.21 & 0.48 & 4.10 & 0.12 & 0.11 & 95.73 \\
\hline $\mathrm{Cr}$ & 24.52 & 23.13 & 4.80 & 4.53 & 19.36 & 18.26 & 1.06 & 1.11 & 95.22 \\
\hline $\mathrm{Cu}$ & 36.31 & 10.09 & 9.60 & 2.67 & 16.62 & 4.62 & 3.60 & 3.55 & 98.53 \\
\hline $\mathbf{F e}$ & 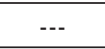 & --- & 78.50 & 0.18 & $4,519.12$ & 10.51 & 430.00 & 413.44 & 96.15 \\
\hline Mn & 197.64 & 3.14 & 72.40 & 1.15 & 181.05 & 2.87 & 63.00 & 60.60 & 96.19 \\
\hline $\mathrm{Ni}$ & 15.84 & 6.46 & 11.40 & 6.46 & 74.25 & 30.29 & $--\cdot$ & 2.45 & $*$ \\
\hline $\mathrm{Pb}$ & 36.42 & 7.43 & 3.70 & 0.76 & 9.95 & 2.03 & 4.90 & 4.75 & 96.89 \\
\hline $\mathrm{V}$ & --- & -.- & $\cdots$ & $\ldots$ & 22.85 & 15.54 & 1.47 & 1.41 & 95.81 \\
\hline $\mathrm{Zn}$ & 153.20 & 5.04 & 97.40 & 3.20 & 162.87 & 5.36 & 30.40 & 28.91 & 95.10 \\
\hline
\end{tabular}

* Since there are no data available in the list of IAEA-336 certified, results of Ni in IÇEL, ÇoBAnoĞLu (2009), and MENDIL et al. (2005) studies have been compared with these of IAEA-336 reference material (Evernia prunastri) in our study. 
According to Table 3, the average / IAEA-336 ratios in the study area vary from $2.03(\mathrm{~Pb})$ to $30.29(\mathrm{Ni})$. In these biomonitoring studies with $P h y$ scia, compared with the results in İstanbul (IÇEL, ÇoBanoĞLU 2009), our study shows significant contamination with $\mathrm{Cd}$ (2 times), Ni (4.7 times) and $\mathrm{Zn}$ (1.1 times) in Isparta, while compared to the study in Trabzon city by Mendil et al. (2005), the present study shows higher concentrations of $\mathrm{Cr}$ (4 times), $\mathrm{Cu}$ (1.7 times), Fe (57.6 times), Mn (2.5 times), Ni (4.7 times), $\mathrm{Pb}$ (2.7 times) and $\mathrm{Zn}$ (1.7 times), except $\mathrm{Cd}$, which is lower (0.8 times). Accordingly, it seems that Isparta possibly has more severe levels of air pollution in terms of these airborne elements separately or perhaps in PM forms.

In addition, a more recent study on airborne element accumulation in Physcia adscendens in Istanbul by Kurnaz, ÇoBanoĞLu (2017) revealed the highest concentrations for $\mathrm{Cd}, \mathrm{Cr}$ and $\mathrm{Fe}$ (descending order continues as follows: $\mathrm{Ni}>\mathrm{V}>\mathrm{Pb}>\mathrm{Al}>\mathrm{As}>\mathrm{Zn}>\mathrm{Mn}$ ). In comparison with the present study, similarly high contents were reported for $\mathrm{Cr}, \mathrm{Fe}, \mathrm{N}$ and $\mathrm{V}$, but unlike in our investigation, the levels of $\mathrm{Cd}$ and $\mathrm{Pb}$ were low. YILDIZ et al. (2008) observed an increase in the $\mathrm{Ni}, \mathrm{Pb}, \mathrm{Zn}$ and chlorophyll a content of Pseudevernia furfuracea in Ankara. A similar study with the same lichen in Çankirı and Çorum cities demonstrated an increase in $\mathrm{Cu}, \mathrm{Ni}, \mathrm{Zn}, \mathrm{Mn}$ and a decrease in chlorophyll $a$ in lichen specimens (YILDIZ et al. 2018). This study, carried out in Isparta, shows similarity with these two studies in terms of Ni concentrations, but not in $\mathrm{Pb}, \mathrm{Mn}$ and $\mathrm{Zn}$ concentrations. The differences are probably due to the types of pollutants lichens were exposed to, or the species of monitoring lichens in general. In Isparta, however, especially high $\mathrm{Ni}, \mathrm{Cd}$ and $\mathrm{Pb}$ levels in the atmosphere are caused by coal-fired heating and traffic.

This comparison of previous studies in bigger cities - which in any cases have greater populations and number of vehicles than Isparta - indicate that the airborne elemental pollution in Isparta is higher due to the extensive use of coal as fossil fuel.

\section{CONCLUSION}

This is the first biomonitoring study with lichens as a bioindicator conducted in Isparta. Thus, the results enlarge the database for future biomonitoring studies in the region. The airborne element deposition in the urban vicinity of Isparta was for the first time monitored by using Physcia aipolia (Ehrh. ex Humb.) Furnr. as a biomonitoring organism.

In addition to the increase in population and greater fossil fuel usage, there is numerous metal, leather, petrochemical, paint and cement industrial plants, which negatively affect air quality of the city. Our results indicate that the degree of elemental deposition is severe in some locations of the city, especially in terms of $\mathrm{Ni}, \mathrm{Cr}, \mathrm{V}, \mathrm{Fe}$ and As elements. Cluster and 
correlation analyses of elements showed that coal combustion and traffic were among the important anthropogenic sources of airborne elements in Isparta. This study proves that the alarming consequences of air pollution in the city should be taken seriously. Regarding the contamination levels in GNP, this study advises precise and careful landscape use in the park, and limitation of human activities to reduce the anthropogenic impact to the minimum in order to achieve sustainable environmental conditions. To prevent degradation of nature in GNP, it is important to monitor the changes determined in this study, and to evaluate their impacts. With regard to contamination levels in the urban area, this study indicates the necessity to use renewable energy or natural gas for heating etc., in order to decrease the concentration of airborne elements in the atmosphere.

Intensive development of industry, transport and urbanization changes the spatial scope of environmental pollution from local to global. Emissions of heavy metals lead to the increase of their concentrations in different ecosystems. Urban agglomerations are most exposed to multidimensional impacts. A more rigorous biomonitoring approach is required, like the one described in this study. This way further results can be achieved and longer-term effects can be observed instead of instant evaluations.

Finally, this study confirms that lichens can be used as an alternative way to efficiently assess levels of airborne elements.

\section{REFERENCES}

Aslan A., Budak G., Karabulut A. 2004. The amounts Fe, Ba, Sr, K, Ca and Ti in some lichens growing in Erzurum province (Turkey). J Quant Spectrosc Ra, 88: 423-431.

Bari A., Rosso A., Minciardi M.R., Troiani F., Piervittori R. 2001. Analysis of heavy metals in atmospheric particulates in relation to their bioaccumulation in explanted Pseudevernia furfuracea thalli. Environ. Monit. Assess., 69: 205-220.

Boonpeng C., Polyiam W., Sriviboon C., Sangiamdee D., Watthana S., Nimis P.L., Boonpragob K., 2018. Airborne trace elements near a petrochemical industrial complex in Thailand assessed by the lichen Parmotrema tinctorum (Despr. ex Nyl.) Hale. Environ Sci Pollut Res., 24(13): 12393-12404. DOI: 10.1007/s11356-017-8893-9

BozkuRT z., 2017. Determination of airborne trace elements in an urban area using lichens as biomonitors. Environ Monit Assess., 189(11): 573. https://doi.org/10.1007/s10661-017-6275-x

Cayir A., Coskun M., Coskun M. 2007. Determination of atmospheric heavy metal pollution in Canakkale and Balikesir Provinces using lichen (Cladonia rangiformis) as a bioindicator. Bull Environ Contam Toxicol., 79: 367-370. DOI: 10.1007/s00128-007-9232-5

ÇobanoĞLU G. 2015. The use of lichens for biomonitoring of atmospheric pollution-atmosferik Kirliliğin Biyolojik Izlenmesinde Likenlerin Kullanımı. Sigma J Engin. Natur Sci, 33(4): 591-613.

Demir K. (Eds) 2010. Isparta Çevre Durum Raporu 2009. Isparta Valiliği, İl Çevre ve Orman Müdürlüğü. 1-494. (in Turkey)

Di Q., Wang Y., Zanobetti A., Wang Y., Koutrakis P., Choirat C., Dominici F., Schwartz J.D. 2017. Air pollution and Mortality in the medicare population. Engl J Med., 376(26): 2513-2522. DOI: 10.1056/NEJMoa1702747

Dogrul-Demiray A., Yolcubal I., Akyol N.H., Cobanoglu G. 2012. Biomonitoring of airborne 
metals using the lichen Xanthoria parietina in Kocaeli Province, Turkey. Ecol. Indic., 18: 632-643.

EPA 2017. Online brochure, https://nepis.epa.gov/Exe/ZyPDF.cgi?Dockey=P1001EX6.txt and https://www.epa.gov/pm-pollution/particulate-matter-pm-basics\#PM

GARTY J. 2001. Biomonitoring atmospheric heavy metals with lichens: Theory and application. Crit. Rev. Plant Sci., 20(4): 309-371.

Giordani P., Brunialti G., Bacaro G., Nascimbene J. 2012. Functional traits of epiphytic lichens as potential indicators of environmental conditions in forest ecosystems. Ecol Indic, 18: 413-420.

Hawksworth D.L, Rose F. 1976. Lichens as pollution monitors. Stud. Biol., 66: 60.

IÇEL Y., ÇoBANoĞLU G., 2009. Biomonitoring of atmospheric heavy metal pollution using lichens and mosses in the city of Istanbul, Turkey. Fresen Environ Bull, 18(11): 2066-2071.

Iмiм 2010. Isparta Meteoroloji Il Müdürlüğü. http://isparta.meteor.gov.tr/ (March 2010)

Kunnaz K. ÇobanoĞLU G. 2017. Biomonitoring of air quality with epiphytic lichen Physcia adscendens (Fr.) H. Olivier in Istanbul, Turkey. Fresen Environ Bull (FEB), 26(12): 7296-7308.

Loppi S., Bosi A., Signorini C., De Dominicis V. 2003. Lichen recolonization of Tilia trees in Arezzo (Tuscany, central Italy) under conditions of decreasing air pollution. Cryptogam Mycol. 24: $175-185$.

Mendil D., Tuzen M., Yazici K., Soylak M., 2005. Heavy metals in lichens from roadsides and an industrial zone in Trabzon, Turkey. Bull. Environ. Contam. Toxicol., 74: 190-194.

ÖlGen M.K., GüR F. 2012. Yatağan Termik Santrali Çevresinden Toplanan Likenlerde. (Xanthoria parietina) Saptanan Ağır Metal Kirliliğinin Coğrafi Dağılışı. Türk Coğrafya. Dergisi, 57: 43-54. (in Turkey)

Parzych A., Astel A., Zduńczyk A., Surowiec T. 2016. evaluation of urban environment pollution based on the accumulation of macro- and trace elements in epiphytic lichens. J Environ Sci Health, part A, 51(4): 297-308.

Pateraki S., Asimakopoulos D.N., Flocas H.A., Maggos T., Vasilakos C. 2012. The role of meteorology on different sized aerosol fractions $\left(P M_{10}, P M_{2.5}, P M_{2.5-10}\right)$. Sci Total Environ, 419: 124-135.

Rauch J.N., Pacyna J.M. 2009. Earth's global Ag, $\mathrm{Al}, \mathrm{Cr}, \mathrm{Cu}, \mathrm{Fe}, \mathrm{Ni}, \mathrm{Pb}$, and $\mathrm{Zn}$ cycles. Global Biogeochem. Cycles, 23(2): GB2001. DOI: 10.1029/2008GB003376

Scerbo R., Ristori T., Possenti L., Lampugnani L., Barale R., Barghigiani C. 2003. Lichen (Xanthoria parietina) biomonitoring of trace element contamination and air quality assessment in Pisa Province (Tuscany, Italy). Sci. Total Environ., 286: 27-40.

ŞEnKardeşler A., Aysel V. 2010. Lichen bioindication in the Karaburun Peninsula (Izmir, Turkey). The Journal of Fungus, 1(2): 13-23.

Wolterbeek H., Garty J., Reis M. A., Freitas M.C. 2003. Biomonitors in use: lichens and metal air pollution. In: Bioindicators and Biomonitors. Markert B.A., Breure A.M., Zechmeister H.G. (Eds): Elsevier. Oxford, 377-419.

Yenisoy-Karakaş S., Tuncel S.G. 2004. Geographic patterns of elemental deposition in the Aegean region of Turkey indicated by the lichen, Xanthoria parietina (L.) Th. Fr. Sci Total Environ, 329: 43-60.

Yildiz A., Aksoy A., Tug G.N., Islek C., Demirezen D. 2008. Biomonitoring of heavy metals by Pseudevernia furfuracea (L.) Zopf in Ankara (Turkey). J Atmos Chem 60: 71-81. DOI: 10.1007/ s10874-008-9109-y

Yildiz A., Vardar Ç., Aksoy A., Ünal E. 2018. Biomonitoring of heavy metals deposition with Pseudevernia furfuracea (L.) Zopf in Çorum city, Turkey. J Sci Perspectives, 2(1): 9-22. 